\title{
Free Cash Flow, Debt Policy and Profitability: Analysis the Investment Opportunity Set
}

\author{
Putri Dwi Wahyuni
}

\section{ABSTRACT}

\begin{abstract}
The main purpose of investors investing in the capital market is to earn profits in the future. Investment is an alternative investment. If investors have excess funds, they will not let their funds idle. Funds can be invested in various forms, such as buying certain assets that tend to increase in price such as equipment, land, or gold or in the form of time deposits in banks, buying stocks and bonds in the financial market. The research objective to be achieved is to provide understanding and knowledge to the public, especially investors and creditors regarding free cash flow, debt policy, profitability and investment opportunity sets that can be used as a reference for further researchers as well as a reference for stakeholders (investors, creditors, and the government) in making decisions. relevant and reliable. The method used is quantitative research with secondary data taken from financial statements at idx with data collection techniques using purposive sampling method. Analysis of the data used is multiple linear regression with panel data. The population in this study is the property and real estate subsector listed on the Indonesia Stock Exchange, which was carried out for 3 years of observation, namely 2017-2019 totaling 120 data with 40 companies per year. The results showed that only the debt policy variable proxied by the debt equity ratio had a significant effect on the investment opportunity set, while the free cash flow and profitability variables proxied by the return on assets had an insignificant effect on the investment opportunity set.
\end{abstract}

Keywords: Debt Policy, Free Cash Flow, Investment Opportunity Set (IOS), Profitability.

\section{INTRODUCTION}

In choosing an investment that can generate the expected return, an investor needs a variety of relevant and reliable information so that investment decisions are right and in accordance with the objectives. Stock investment analysis is a fundamental thing for investors to know because without a good and rational analysis, investors will experience losses. Stock investment analysis can be divided into two approaches, namely technical analysis, and fundamental analysis [13]. These investment options in the future are known as the investment opportunity set (IOS). IOS is the availability of investment alternatives in the future for companies [8]. To achieve company goals, managers make investment decisions that result in positive net present value. The investment opportunity set (IOS) is a combination of assets owned by the company (assets in place) and the selection of future investments with a positive net present value [21]. IOS is the value of the company whose amount depends on the expenditures set by management in the future which are current investment choices and are expected to generate greater returns [4]. Companies with high IOS tend to be rated positively by investors because they have more profit prospects in the future [22]. Investment opportunity set is influenced by free cash flow, debt policy set by the
Submitted : July 02, 2021

Published : July 24, 2021

ISSN: 2507-1076

DOI: $10.24018 /$ ejbmr.2021.6.4.968

Putri Dwi Wahyuni*

Universitas Mercu Buana, Jakarta,

Indonesia.

(e-mail: putri.dwi@ ${ }^{@}$ mercubuana.ac.id

*Corresponding Author company and profitability. For companies going public, IOS is one of the things that managers want because from IOS, companies can get more company value in getting profitability in the future. Investment opportunities apart from being seen from the number of expenses that are set to be used for the company's needs in the future. One way to predict IOS in the future is to calculate the company's free cash flow (FCF). When the company has made investments that are expected to generate profits in the future, has paid debts and distributed dividends, but still has cash remaining, this is called free cash flow [2]. In addition, Free Cash Flow is cash that is freely distributed by the company to creditors and shareholders which is no longer needed for working capital or investment in fixed assets [18]. Debt policy is a way for companies to take advantage of external funding facilities (debt) so that the amount of their use can minimize the amount of risk that must be borne by the company. The greater the proportion of company debt, the higher the principal and interest costs that must be paid back and the higher the risk of bankruptcy [7].

Profitability is a measure of the company's ability to obtain profits or net results from each company's policies and decisions and can be calculated from relevant benchmarks, one of which is financial ratios [1]. Profitability can be projected by Return on Assets (ROA). Profitability projections using Return on Assets (ROA) show the results of 
the company's net income for the current year to the company's total assets for the current year. In this case, it can be seen how big the total assets owned by the company are to generate the company's profit for the current year. Companies with high profitability have a large enough retained earnings so that they will have a large enough opportunity for the Investment Opportunity Set because investors who will invest their funds will choose and consider these things.

The sectors used in this research are the property and real estate sectors. Property and real estate companies are companies engaged in property and real estate services. The reason for choosing the property and real estate sector is because stocks in this sector are stocks that are able to withstand changes in economic environmental conditions or economic crises compared to other sectors. The property sector is one of the most important sectors in Indonesia. The property sector is an important indicator to analyze the economic health of a country. The property industry is also the first sector to signal the fall or rise of a country's economy. Apart from these reasons, this sector was chosen as the object of research because this sector is one of the sectors with quite high volatility.

Year to date, the property sector index recorded an increase of $7 \%$, the second highest after mining. The property price index in the fourth quarter of 2017 was recorded at 201,36. An increase compared to the previous quarter which was 200,26 and the same period in 2016 which was 194,54 . In the first quarter of 2018, the property index is expected to rise again to 201,36 . The increase in the price of building materials and the wages of workers are still the cause of the increase in property prices.

The growth of the property sector, which is still shiny, makes it one of the assets for hedging. In the midst of a volatile market, investors need a place to secure their assets and property becomes an option. This causes the performance of property issuers to remain good when the market is surging. The property index's performance was also decent, growing $7,14 \%$ year to date (YtD) which only lost to the mining sector with growth of $21,73 \%$. (https://www.cnbcindonesia.com/).

There is still a research gap that occurs in research on the effect of free cash flows, debt policy and profitability on the Investment Opportunity Set, including research conducted [14] which states that free cash flow has a significant effect to the investment opportunity set. The results of the study [19] show that there is a negative and significant effect between funding policies on the investment opportunity set. Meanwhile, according to research [13] debt policy has no effect on the investment opportunity set. The effect of profitability as proxied by return on assets on the investment opportunity set is significant positive. Research [20] shows that funding policy and dividend policy affect the Investment Opportunity Set while profitability has no effect on the Investment Opportunity Set. Another study conducted by [24] examined the factors that influence the Investment Opportunity Set. The results showed that the profitability and activity variables had a positive effect on the Investment Opportunity Set, the dividend policy variable had a negative effect on the Investment Opportunity Set. Meanwhile, the investment risk, liquidity, and debt policy variables have no effect on the Investment Opportunity Set.

\section{LITERATURE REVIEW AND HYPOTHESIS}

\section{A. Agency Theory}

Agency theory is concerned with contractual relationships between members of a company or organization. The most widely used model focuses on two individuals, namely the principal (supervisor) and agent (subordinate) and is viewed from a behavioral and structural perspective [10].

Company performance by minimizing costs and increasing efficiency is the desired outcome by agency theory perspective [5]. According to [16], in general, it is possible that some firms exhibit high investment cash flow sensitivity due to information asymmetry (such firms will underinvest), whereas others may suffer from overinvestment caused by agency costs of cash flows. Free cash companies that have high free cash flow have a tendency to have high debt, especially for companies that have low investment opportunities, high debt is intended to offset the occurrence of agency costs that come from free cash flow [14].

\section{B. Pecking Order Theory}

According to [15] pecking order theory states that companies with high levels of profitability actually have low levels of debt, because companies with high profitability have abundant internal sources of funds. External funds are preferred in the form of debt over equity for two reasons. First, the consideration of the cost of issuing bonds is cheaper than the cost of issuing new shares. Second, managers are worried that the issuance of new shares will be interpreted as bad news by investors and make the stock price fall.

\section{Investment Opportunity Set (IOS)}

Company as a combination of assets in place and future investment opportunities. The component of firm value that results in the choice to make future investments is called the Investment Opportunity Set or IOS) [15].

IOS proxies vary in form and are classified into 3 main types [4] and [11] namely: IOS proxies based on price; IOS proxies based on investment; IOS proxy based on variance.

In this study, IOS proxy is used based on price because growing companies will have a higher relative market value compared to their assets. IOS based on price is a proxy which states that the company's growth prospects are partly expressed in market prices. This IOS proxy is based on the idea that the company's growth prospects are partially incorporated in the stock price, and growth will be greater than market value relative to assets in place [9].

The choice of proxy refers to Anugrah's research in [9]. The MVBVA formula is:

$\underline{\text { Total Asset }- \text { Total Equity }+(\text { Outstanding Shares } \times \text { Closing Price })}$ Total Asset

\section{Free Cash Flow}

Free cash flow as discretionary cash flow available to the company. Free cash flow is cash from operating activities minus capital expenditures spent by the company to meet current production capacity [23].

\section{E. Debt Policy}

Debt policy is the company's policy to take advantage of external funding facilities. Debt policy can be influenced by 
the company's special characteristics that affect the company's debt supply curve or the demand for debt. Financing with debt has three important implications (1) obtaining funds through debt allows shareholders to maintain control over the company with limited investment, (2) creditors look to equity or funds deposited by owners to provide a margin of safety, so that if shareholders only provide part If the company gets a greater return on investment financed with loan funds compared to interest payments, then the return on owner's capital will be greater. Debt ratio is total debt (both short-term and long-term debt) divided by total assets (both current assets and fixed assets) [12].

\section{F. Profitability}

Most investors and creditors use profitability as a benchmark in assessing how effectively the company manages its resources. Profitability is also the basis for consideration for investors and creditors in making decisions to invest their funds. Profitability is income to finance investments aimed at generating profits.

The level of profitability assumes that companies with large profits will have a good opportunity to compete with the same types of companies in the future [19].

\section{G. Hypothesis Development}

\section{1) Effect of Free Cash Flow on Investment Opportunity Set}

Free cash flow is the company's excess cash distributed to creditors or shareholders that is no longer needed for working capital or investment in fixed assets [18]. Free cash flow is cash generated by operations that is not required to fund a net present value project. Thus, the presence of free cash flow problems indicates a bad IOS. The agency costs associated with free cash flow: managers may be tempted to increase required consumption or spend free cash flow on non-optimal investments such as erroneous acquisitions or non-positive net present value projects. Rational markets recognize the existence of these costs and penalize firms with free cash flow by bargaining for equity prices [10]. Managers can reduce the agency costs of free cash flow by entering into contracts or making other commitments that require periodic cash payments. One type of contract that requires periodic cash payments is debt. Jensen predicts that firms with high levels of free cash flow will prefer debt over equity in capital structure decisions, in order to reduce the agency costs of free cash flow. The greater the free cash flow available, the higher the investment opportunities in the company. Companies with high growth with large investment opportunities prefer to fund their investments internally. According to [14] that free cash flow has a positive effect on the investment opportunity set. Based on the description above, thus the first hypothesis in this study is as follows:

H1. Free cash flow has a positive effect on the investment opportunity set.

\section{2) The Effect of Debt Policy on the Investment Opportunity Set}

Debt policy is a policy taken by the company to finance through debt. Debt policy is often measured by the debt ratio. The debt ratio is the total debt (both short-term and long-term debt) divided by total assets (both current assets and fixed assets) [12]. This ratio shows the amount of debt used by the company in carrying out its operational activities. The greater the ratio indicates the greater the level of dependence of the company on external parties (creditors) and the greater the cost of debt (interest costs) that must be paid by the company. Debt policy is more effective in reducing agency cost of equity because of the legal liability of management to fulfill its obligations to creditors related to bankruptcy costs.

According to pecking order theory [15], external funds are preferred in the form of debt rather than equity for two reasons. First, the consideration of the cost of issuing bonds is cheaper than the cost of issuing new shares. Second, managers are worried that the issuance of new shares will be interpreted as bad news by investors and make stock prices go down, this is due to information asymmetry between management and investors so that every manager's behavior is often used as a signal about the condition and prospects of the company [17]. In the pecking order model explains that debt will usually increase when investment exceeds retained earnings and debt will decrease if investment is less than retained earnings [3]. The higher the level of corporate leverage, the smaller the investment opportunity, because the company still has an obligation to make periodic payments of high principal and interest on loans so that it can cause the company's cash flow to decrease. This means that the higher the company's leverage, the smaller the company's reinvestment will be because the company still has a financial risk burden on the leverage. According to [19] that the funding policy proxied by leverage has an effect on the investment opportunity set. Based on the description above, thus the second hypothesis in this study is as follows:

H2. Debt policy has a negative effect on the investment opportunity set.

\section{3) The Effect of Profitability on the Investment Opportunity Set}

Profitability is the company's ability to earn a profit or profit. Profitability is the company's ability to pay dividends to shareholders and retained earnings by the company. Retained earnings can be used as an internal source of funds in financing the company's needs. Based on the Pecking Order Theory where investment financing needs are prioritized using internal funding sources first and then using external funding sources, the company's retained earnings can be used by the company as financing from internal sources to meet the company's needs through a set of investment opportunities. The relationship between profitability and the Investment Opportunity Set is that companies that have high profitability are likely to have high retained earnings as well. High retained earnings will provide flexibility to the company to meet the financing needs of the investment opportunities it has. Profitability in this study uses the ratio of Return on Assets (ROA). Companies with a high rate of return have a greater ability to expand. Profitability is income to finance investments aimed at generating profits. The higher the profitability, the greater the investment opportunities that can be run. According to [24] that profitability has a positive effect on the investment opportunity set. Based on the description above, thus the third hypothesis in this study is as 
follows:

H3. Profitability has a positive effect on the investment opportunity set.

\section{RESEARCH METHODS}

In this study, the type of research used is causal research, which is to explain the effect of an independent variable on the dependent variable. The independent variables in this study include free cash flow, debt policy as proxied by the debt equity ratio and profitability as proxied by return on assets (ROA) while the dependent variable is the investment opportunity set.

\section{A. Population and Sample}

The population of this study is the property and real estate sub-sector companies listed on the Indonesia Stock
Exchange. The sample used in this study is property and real estate companies listed on the Indonesia Stock Exchange in 2017-2019. The reason for choosing the property and real estate sector in this study is because the growth of the property sector which is still shiny makes it one of the assets for hedging. In the midst of a volatile market, investors need a place to secure their assets and property becomes an option. The sampling method used is purposive sampling, namely sampling based on certain criteria

\section{B. Analysis Method}

The data analysis method in this research is descriptive analysis and verification. The verification analysis in this study uses panel data regression analysis (pooled data). Classical assumption test is not needed in panel data analysis because panel data can minimize bias that is likely to appear in the analysis results, provide more information, variation, and degree of freedom [6].

\begin{tabular}{|c|c|c|c|c|}
\hline No & Variable & Definition & Measurement & References \\
\hline 1 & $\begin{array}{l}\text { Investment } \\
\text { Opportunity } \\
\text { Set }\end{array}$ & $\begin{array}{l}\text { This ratio reflects the } \\
\text { company's growth expressed in } \\
\text { market prices }\end{array}$ & $\frac{\text { Total Asset }- \text { Total Equity }+(\text { Outstanding shares } \times \text { closing price })}{\text { Total Asset }}$ & [9] \\
\hline 2 & $\begin{array}{l}\text { Free Cash } \\
\quad \text { Flow }\end{array}$ & $\begin{array}{l}\text { Subtracting operating cash } \\
\text { flow by net capital expenditure } \\
\text { and net working capital }\end{array}$ & $F C F=A K O-P M-M K B$ & {$[18]$} \\
\hline 3 & Debt Policy & $\begin{array}{l}\text { Comparison between total debt } \\
\text { and total assets }\end{array}$ & Debt Ration $=\frac{\text { Total Liability }}{\text { Total Asset }}$ & [12] \\
\hline 4 & Profitability & $\begin{array}{c}\text { The level of net profit that can } \\
\text { be obtained by the company } \\
\text { when carrying out its } \\
\text { operations }\end{array}$ & $R O A=\frac{\text { Earning after Tax }}{\text { Total Asset }} \times 100 \%$ & {$[13]$} \\
\hline
\end{tabular}

\section{RESULT AND DISCUSSION}

\section{A. Result}

1) Descriptive Statistical Analysis TABLE II: DESCRIPTIVE STATISTICAL ANALYSIS

\begin{tabular}{ccccc}
\multicolumn{5}{c}{ TABLE II: DESCRIPTIVE STATISTICAL ANALYSIS } \\
\hline IOS & \multicolumn{1}{c}{ FCF } & DER & ROA \\
\hline Mean & 1.102220 & $-2.59 \mathrm{E}+12$ & 0.344510 & 0.034874 \\
Median & 0.774981 & $-9.61 \mathrm{E}+11$ & 0.337075 & 0.028831 \\
Maximum & 7.957506 & $2.5 \mathrm{E}+12$ & 0.787278 & 0.258529 \\
Minimum & 0.227632 & $-4.22 \mathrm{E}+13$ & 0.024303 & -0.066414 \\
Std. Dev. & 1.111497 & $6.23 \mathrm{E}+12$ & 0.186776 & 0.052949 \\
Skewness & 3.721879 & -4.528727 & 0.172252 & 1.173589 \\
Kurtosis & 19.66211 & 25.54493 & 2.316114 & 5.515035 \\
Jarque-Bera & 1665.177 & 2951.556 & 2.931921 & 59.17320 \\
Probability & 0.000000 & 0.000000 & 0.230856 & 0.000000 \\
Sum & 132.2664 & $-3.11 \mathrm{E}+14$ & 41.34118 & 4.184845 \\
Sum Sq. Dev. & 147.0156 & $4.62 \mathrm{E}+27$ & 4.151349 & 0.333623 \\
Observations & 120 & 120 & 120 & 120
\end{tabular}

Investment Opportunity Set is an option in investing in the future that has a high enough rate of return so that it can make the value of the company also increase with a combination of assets owned by the company. In the table above, the mean value is 1,10 which means that the investment opportunity owned by the company is $1,10 \%$ and is still relatively low so that on average, property sector companies have a low rate of return in investing. The maximum value of 7,95 is owned by TARA in 2018. The minimum value is 0,22 which is owned by GWSA in 2018. Free Cash Flow Free cash flow is cash generated by operations that is not required to fund the project's net present value. In the table above, the mean value is $-2,59$ trillion rupiah, which means that the average free cash flow owned by property and real estate sector companies is negative $(\mathrm{FCF} \leq 0)$ i.e., the company is unable to support expansion due to lack of funds, so the company must issue shares to increase capital and result in reduced profits per share of the company. The maximum value of 2,52 trillion rupiah is owned by ASRI in 2017. The minimum value of 42,207 trillion rupiah is owned by LPKR in 2017. Debt Policy, which is proxied by the debt equity ratio, is the company's policy to utilize external funding facilities. Debt policy can be influenced by the company's special characteristics that affect the company's debt supply curve or the demand for debt. Debt policy is often measured by the debt ratio which is the total debt (both short-term and longterm debt) divided by total assets (both current assets and fixed assets). In the table above, the mean value is 0,344 , which means that the company utilizes external funding facilities of $34,45 \%$ which is categorized as large enough so that the demand for debt made by the company is quite large. The maximum value of 0,78 or $78,72 \%$ is owned by PLIN in 2017. The minimum value is 0.0234 or $2,34 \%$ owned by LCGP in 2019. Profitability proxied by return on assets is the company's ability to earn profits or profits. Profitability is the company's ability to pay dividends to shareholders and retained earnings by the company. In the table above, the mean (average) value is 0,03 or $3,48 \%$ which means that the ability of property and real estate sector companies to earn profits is very small. The maximum value of 0,25 or $25,85 \%$ is owned by LPCK in 2018 . The minimum value is $-0,06$ or 6,64\% owned by ELTY in 2019.

\section{2) Estimation Model Selection}

Based on the estimation technique, the regression model 
with panel data can be estimated using three estimation models, namely the Common Effect Model (CEM), Fixed Effect Model (FEM) and Random Effect Model (REM).

TABLE III: CHOW TEST

\begin{tabular}{lccc}
\hline Reducant Fixed Efefcts Tests & & & \\
Equation: Untitled & & & \\
Test cross-section fixed effects & & & \\
$\quad$ Effects Test & Statistic & df. & Prob. \\
Cross-section F & 15.111975 & $(39,77)$ & 0.0000 \\
Cross-section Chi-square & 258.964225 & 39 & 0.0000 \\
\hline
\end{tabular}

Based on the results of the Chow test above, the probability value of the cross-section $\mathrm{F}$ of $0,0000<0,05$ then $\mathrm{H} 1$ is accepted, which means that the selected Fixed Effect Model then performs Hausman test.

TABLE IV: HAUSMAN TEST

\begin{tabular}{|c|c|c|c|}
\hline \multicolumn{4}{|c|}{$\begin{array}{l}\text { Correlated Random Effects - Hausman Test } \\
\text { Equation: Untitled } \\
\text { Test cross-section random effects }\end{array}$} \\
\hline Test Summary & Chi, Sq. Statistic & Chi-Sq df. & Prob. \\
\hline $\begin{array}{l}\text { Cross-section } \\
\text { random }\end{array}$ & 9.952857 & 3 & 0.0190 \\
\hline
\end{tabular}

Based on the results of the Hausman test above, a random cross-section probability value of $0.0190<0.05$ is obtained, then $\mathrm{H} 1$ is accepted, which means that the selected fixed effect model does not need to perform the Lagrange Multiplier test.

The conclusion is that from the Chow test and Hausman test that have been carried out, the fixed effect model is selected.

\section{3) Identification of Panel Data Regression Equation} Estimation Results

\begin{tabular}{ccccc}
\multicolumn{5}{c}{ TABLE V: REGRESSION PANEL DATA } \\
\hline Variable & Coefficient & Std. Error & t-Statistic & Prob. \\
C & 0.218340 & 0.235717 & 0.926281 & 0.3572 \\
FCF & $3.12 \mathrm{E}-14$ & $3.63 \mathrm{E}-14$ & 0.859654 & 0.3926 \\
DER & 2.750976 & 0.613698 & 4.482626 & 0.0000 \\
ROA & 0.490363 & 1.356564 & 0.361475 & 0.7187 \\
\hline \multicolumn{5}{c}{ Effects Specification } \\
Cross-section fixed (dummy variables) \\
Adjusted R- & 0.887932 & Mean dependent var & 1.102220 \\
squared & 0.826804 & S.D. dependent var & 1.111497 \\
S.E. of regression & 0.462570 & Akaike info criterion & 1.568942 \\
Sum squared resid & 16.47576 & Schwarz criterion & 2.567793 \\
Log likelihood & -51.13652 & Hannan-Quinn criter. & 1.974580 \\
F-statistic & 14.52577 & Durbin-Watson stat & 2.749814 \\
Prob (F-statistic) & 0.000000 & & \\
\hline
\end{tabular}

\section{4) Coefficient of Determination}

Based on the table above, it shows that the coefficient of determination indicated by the R-squared value is 0,8879 , which means $88,79 \%$ of the variation in the amount of free cash flow, debt equity ratio and return on assets, while (100\% $-88,79 \%)=11,21 \%$ of the total investment opportunity set. proxied by MVBVA is explained by other variables that are not included in this research model.

\section{5) Statistical F Test}

The F-statistical test in this study shows a probability value (F-Statistic) of $0 .,<0,05$, which means that this research model is feasible to use.

6) T-statistic test

Based on the table above, the partial test results can be seen as follows:

1. The probability value of free cash flow is 0,3926 with a significant $5 \%(0,05)$ so $\mathrm{H} 1$ is rejected. This means that free cash flow has a positive but not significant effect on the investment opportunity set

2. The probability value of debt policy proxied by the debt equity ratio is 0,0000 with a significant $5 \%(0,05)$ then $\mathrm{H} 2$ is accepted. This shows that debt policy has a positive and significant effect on the investment opportunity set.

3 . The probability value of profitability as a proxy for return on assets is 0,7187 with a significant $5 \%(0,05)$ then $\mathrm{H} 3$ is rejected. This means that profitability has a positive but significant effect on the investment opportunity set.

\section{B. Discussion}

\section{1) Effect of Free Cash Flow on Investment Opportunity Set}

Free cash flow has a positive but not significant effect on the investment opportunity set. This is contrary to agency theory. The agency costs associated with free cash flow: managers may be tempted to increase required consumption or spend free cash flow on non-optimal investments such as erroneous acquisitions or non-positive net present value projects. Rational markets recognize the existence of these costs and penalize firms with free cash flow by bargaining for equity prices [10]. Managers can reduce the agency costs of free cash flow by entering into contracts or making other commitments that require periodic cash payments. One type of contract that requires periodic cash payments is debt Jensen predicts that firms with high levels of free cash flow will prefer debt over equity in capital structure decisions, in order to reduce the agency costs of free cash flow. The greater the free cash flow available, the higher the investment opportunities in the company. However, this is not proven in this study, large or small free cash flow owned has no effect on investment opportunities. Another factor that causes no significant effect on the investment opportunity set is because the free cash flow of property and real estate sector companies has a negative value on average, which means that the company has a shortage of funds to develop its business so that the tendency to have high debt and low investment opportunities. The results of this study contradict the research conducted by (Lusiana et al., 2016) which states that free cash flow has a positive and significant effect on the investment opportunity set.

\section{2) The Effect of Debt Policy on the Investment Opportunity} Set

Debt policy has a positive and significant effect on the investment opportunity set. This is in line with agency theory and pecking order theory. Debt policy is more effective in reducing agency cost of equity because of the legal liability of management to fulfill its obligations to creditors related to bankruptcy costs. According to pecking order theory [15], external funds are preferred in the form of debt rather than equity for two reasons. First, the consideration of the cost of issuing bonds is cheaper than the cost of issuing new shares. Second, managers are worried that the issuance of new shares will be interpreted as bad news by investors and make stock prices fall, this is due to the information asymmetry between management and investors so that every manager's behavior is often used as a signal about the condition and prospects of the company. The results of this study have a positive 
relationship according to [3] in the pecking order model explaining that debt will usually increase when investment exceeds retained earnings and debt will decrease if investment is less than retained earnings. So that the greater the company's debt, the greater the company's investment opportunities because the company has additional funds from external parties to manage it in the form of investment. The results of this study are in line with research conducted [19] that funding policies proxied by leverage affect the investment opportunity set.

\section{3) The Effect of Profitability on the Investment Opportunity} Set

Profitability has a positive but not significant effect on the investment opportunity set. This is contrary to the pecking order theory where investment financing needs are prioritized using internal funding sources first and then using external funding sources, then the company's retained earnings can be used by the company as financing from internal sources to meet the company's needs through a set of investment opportunities. The relationship between profitability and the Investment Opportunity Set is that companies that have high profitability are likely to have high retained earnings as well. High retained earnings will provide flexibility to the company to meet the financing needs of the investment opportunities it has. However, the results of this study have not proven that profitability has a significant effect on the investment opportunity set because the average level of profitability of the property and real estate sector companies is still relatively small, namely $3.48 \%$ so that investment opportunities in the future are still low due to internal funding sources from the profits generated. still small. This is contrary to research conducted by [24] that profitability has a positive effect on the investment opportunity set. But in line with research [20] shows that profitability has no effect on the Investment Opportunity Set.

\section{CONCLUSION}

Based on the results of the tests that have been carried out, it is only the debt policy that is proxied by the debt equity ratio that has a significant effect. This is because debt will usually increase when investment exceeds retained earnings and debt will decrease if investment is less than retained earnings. So that the greater the company's debt, the greater the company's investment opportunities because the company has additional funds from external parties to manage it in the form of investment. Meanwhile, free cash flow and profitability have an insignificant effect on the investment opportunity set.

\section{REFERENCES}

[1] Brigham, E., \& Houston, J. (2014). Fundamentals of Financial Management, Concise Edition. Retrieved from https://books.google.com/books?id=kpEK-UaGGsYC\&pgis=1 .

[2] Bujana, N. K. A. S., \& Yaniartha, P. D. (2015). Pengaruh Fee Cash Flow dalam Memprediksi Laba dan Arus Kas Operasi Masa Mendatang. E-Journal Akuntansi Universitas Udayana, 10(3), 618631.

[3] Fama, E. F., \& French, K. R. (2002). Testing Trade-Off and Pecking Order Predictions About Dividends and Debt. The Review of Financial Studies, 15(1), 1-33.

[4] Gaver, J. J., \& Gaver, K. M. (1995). Policy and Set Opportunity.
Financial Management, 24(1), 19-32.

[5] Ghozali, I. (2020). 25 Grand Theory Ilmu Manajemen, Akuntansi dan Bisnis. Yoga Pratama : Yogjakarta.

[6] Gujarati, D. N. (2012). Essentials of Econometrics (Terjemahan) (pp. 1-250). pp. 1-250. Indonesia: Erlangga.

[7] Gusti, B. F. (2013). Pengaruh Free Cash Flow Dan Struktur Kepemilikan Saham Terhadap Kebijakan Hutang Dengan Investment Opportunity Set Sebagai Variabel Moderating. Jurnal Akuntansi, 1(2), $1-25$.

[8] Hartono, J., \& Ratnaningsih, D. (2003). A mechanism and determinants of an agency-cost explanation for dividend payments. Gadjah Mada International Journal of Business, 5(2), 145-166.

[9] Hidayah, N. (2015). Pengaruh Investment Opportunity Set (Ios) Dan Kepemilikan Manajerial Terhadap Nilai Perusahaan Pada Perusahaan Property Dan Real Estat Di Bursa Efek Indonesia. Jurnal Akuntansi, 19(3), 420-432. https://doi.org/10.24912/ja.v19i3.89.

[10] Jensen, M., \& Meckling, W. (1976). Theory of the firm: Managerial behaviour, agency costs and ownership. Strategic Management Journal, 21(4), 1215-1224.

[11] Kallapur, S., \& Trombley, M. A. (2001). The Investment Opportunity Set: Determinants, Consequences and Measurement. Managerial Finance, 27(3), 3-15. https://doi.org/10.1108/03074350110767060.

[12] Kieso, Weygandt, \& Warfield. (2018). Non Current Liabilities. In Intermediate Accounting IFRS Edition (third). California: WILEY.

[13] Kusumawati, D., \& Safiq, M. (2019). Analisis Faktor-Faktor Yang Mempengaruhi Investment Opportunity Set Dan Implikasinya Terhadap Return Saham. Jurnal STEI Ekonomi, 28(01), 1-27. https://doi.org/10.36406/jemi.v28i01.258.

[14] Lusiana, R., Mufidah, F., \& Habibah, N. (2016). Pengaruh Tingkat Free Cash Flow Terhadap Investment Opportunity Set Pada Perusahaan Makanan dan Minuman Yang Terdaftar Di Bursa Efek Indonesia. The Asia Pacific Journal of Management Studies, 3(2), 83-88.

[15] Myers, S. C. (1977). Determinants of Corporate Borrowing. Journal of Financial Economics, 5, 147-175. https://doi.org/10.1253/circj.CJ-160846.

[16] Pawlina, G., \& Renneboog, L. (2005). Is investment-cash flow sensitivity caused by agency costs or asymmetric information? evidence from the UK. European Financial Management, 11(4), 483513. https://doi.org/10.1111/j.1354-7798.2005.00294.x.

[17] Ramdani, \& Argamaya. (2016). Pengaruh Kebijakan Utang, Risiko Investasi dan Ukuran Perusahaan Terhadap Investment Opportunity Set (Studi pada Industri Makanan dan Minuman yang Terdaftar di Bursa Efek Indonesia Tahun 2010-2014). Jurnal Ilmiah Universitas Bakrie, 4(1), 1-19.

[18] Ross, Westerfield, \& Jaffe. (2003). Corporate Finance. In Corporate Finance (Vol. 6). https://doi.org/10.1108/eb040123.

[19] Saputro, A. A., \& Hindasah, L. (2007). Pengaruh Kebijakan Pendanaan, Dividen dan Profitabilitas Perusahaan terhadap Set Kesempatan Investasi (IOS). Jurnal Akuntansi Dan Investasi, 8(1), 5871.

[20] Syarifah, Z., \& Zuhrotun. (2009). Pengaruh Kebijakan Pendanaan, Kebijakan Dividen dan Profitabilitas Terhadap Investment Opportunity Set Manufaktur PUblik. Buletin Ekonomi, 7(2), 131-246.

[21] Wahyudi, S. M. (2020). The Effect of Corporate Social Responsibility, Investment Opportunity Set, Leverage, And Size of Companies on Corporate Value. European Journal of Business and Management Research, 5(4), 1-7. https://doi.org/10.24018/ejbmr.2020.5.4.455.

[22] Warianto, P., \& Ch.Rustiti. (2014). Pengaruh Ukuran Perusahaan, Struktur Modal, Likuiditas, dan Investment Opportunity Set (IOS) Terhadap Kualitas Laba di Perusahaan Manufaktur Yang Terdaftar di BEI. Modus Journals, 26(1), 19-32.

[23] White, G. I., Sondhi, A. C., \& Fried, D. (2003). The Analysis and Use of Financial Statements (pp. 1-767). pp. 1-767.

[24] Yendrawati, R., \& Adhianza, F. R. (2013). Faktor-Faktor Yang Berpengaruh Terhadap Set Kesempatan Investasi (Ios) Pada Perusahaan. Jurnal Inovasi Dan Kewirausahaan, 2(1), 32-41. 